\title{
Analisis Penggunaan WhatsApp Sebagai Media PembelajaranBahasa Arab di Era Industri 4.0
}

\author{
Muhamad Arif Mustofa \\ Institut Agama Islam Negeri (IAIN) Curup \\ aripatmi@gmail.com
}

\begin{abstract}
The purpose of this study is to describe the use of Whatsapp in learning Arabic and the principles of media selection in the era 4.0. The digital era or commonly known as the industrial era 4.0, learning that runs must use technology that makes it easier for teachers and students to carry out the teaching and learning process, as well as learning Arabic. Whatsapp as a medium that is widely used today can be used for learning Arabic. This research is librarybased, so that the data obtained through deepening the text of books or articles is in accordance with the required data. Then the data were analyzed and described. This article provides an answer by explaining that the principles of media selection in the 4.0 era are clarity of media intentions, familiarity, and clear guidelines for their use. The use of Whatsapp for learning Arabic using the Whatsapp group and unbeatable text, voice, video and file messaging services with language skills that will teach.
\end{abstract}

Keywords: Media, Arabic language, Industri 4.0

\begin{abstract}
Abstrak
Tujuan penelitian ini untuk memaparkan penggunaan Whatsapp dalam pembelajaran bahasa Arab serta prinsip pemilihan media pengajaran di era 4.0. Di era digital atau biasa dikenal dengan era industri 4.0, pembelajaran yang berjalan harus disertai dengan penggunaan teknologi yang mempermudah guru dan peserta didik dalam melaksanakan proses belajar mengajar, begitu juga dengan pembelajaran bahasa Arab.Whatsapp sebagai salah satu media yang banyak digunakan saat ini bisa dimanfaatkan untuk pembelajaran bahasa Arab. Penelitian ini berbasis pustaka, sehingga data yang diperoleh melalui pendalaman terhadap teks-teks buku maupun artikel sesuai data yang dibutuhkan. Kemudian data dianalisis dan dideskripsikan.Artikel ini memberikan jawaban dengan memaparkan bahwa prinsip pemilihan media pengajaran di era 4.0 yaitu kejelasan
\end{abstract}


maksud dan tujuan media, familiar, serta adanya panduan yang jelas dalam pemanfaatannya. Penggunaan Whatsapp untuk pembelajaran bahasa Arab dengan menggunakan grup Whatsapp serta layanan pesan tulis, suara, video dan file yang disesuaikan dengan keterampilan bahasa yang akan diajarkan.

Kata Kunci: Media, bahasa Arab, Industri 4.0

\section{Pendahuluan}

Bahasamerupakan media atau sarana komunikasi yang paling efektif digunakan. Sebagai makhluk sosial, interaksi antara satu dengan yang lain menjadi kebutuhan yang tidak terelakkan. Keinginan dan kebutuhan seseorang terhadap yang lain bisa tersampaikan dengan cepat melalui bahasa yang digunakan. Hal ini senada dengan yang diungkapkan oleh Ibnu Jinni, bahwa bahasa merupakan ujaran yang digunakan seseorang dalam menyampaikan maksud dan tujuannya. ${ }^{1}$

Dalam bahasa Arab, ada beberapa skil sebagai ketrampilan berbahasa yang menjadi target bagi siapa saja yang mempelajarinya. Ketrampilan tersebut terbagi menjadi empat yang tersusun secara hirarki berurutan dan tidak seharusnya diacak dalam mempelajarinya. Empat ketrampilan bahasa yang dimaksud yaitu: maharah istima' (mendengar), maharah kalam (berbicara), maharah qiroah (membaca), dan maharah kitabah (menulis).

Bahasa Arab sebagai bahasa asing atau bahasa ke dua bagi pelajar Indonesia tentu dalam pengajaran dan pembelajarannya terdapat kendala dan kesulitan. Kendala yang dihadapi beraneka ragam, mulai dari perbedaan karakteristik bahasa Arab dengan bahasa Indonesia maupun minat dan semangat peserta didik itu sendiri dalam mempelajarinya.

Dengan adanya kendala tersebut, para guru bahasa Arab dituntut mampu menyampaikan pelajaran dengan baik dan tepat. Penguasaan materi menjadi bagian penting untuk dikuasai guru disamping juga mereka harus dapat memilah dan memilih metode dan media yang digunakan. Dengan pemilihan metode dan media yang tepat, peserta didik akan merasa asik untuk belajar bahasa Arab sehingga tumbuh semangat dan cinta mempelajari bahasa Arab itu sendiri.

Media merupakan salah satu factor yang mendukung terselenggaranya pembelajaran dengan baik. Melalui media, guru dapat menjelaskan lebih mudah serta mengurangi penjelasan secara verbal dan tertulis serta dapat menjawab persoalan meskipun dengan ruang dan waktu yang terbatas.

Media itu sendiri, dari segi definisi diambil dari kata medius yang secara

\footnotetext{
${ }^{1}$ Utsman Ibn Jinni \& Abd. Fatah, Al-Khashais (Bairut: Alam al-Kutub, n.d.)., 19
} 
bahasa berarti tengah, perantara dan pengantar. ${ }^{2}$ Media pembelajaran dirasasangat urgen terlebih di tengah terjadinya wabah pandemic corona. Guru dituntut untuk tetap dapat memberikan pengajaran terhadap murid-muridnya melalui berbagai media. Dari perspektif di atas, maka perlu rasanya adanya tulisan yang menjelaskan berbagai macam media pembelajaran digital khususnya dalam pembelajaran bahasa Arab sehingga guru akan lebih mudah dalam menyampaikan pelajaran.

Pada era revolusi 4.0, setiap orang dituntut secara cepat dan tanggap dalam beradaptasi dengan pemanfaatan teknologi. Teknologi digital menjadi sarana penting dalam melakukan banyak kegiatan, mulai dari kegiatan ekonomi (digital economy), kecerdasan buatan, big data, dan lain sebagainya yang umum dikenal dengan era disrupsi.

Aplikasi yang kini umum dan acap kali digunakan sebagai sarana komunikasi adalah WA. Aplikasi ini menyediakan beberapa layanan yang cukup lengkap, murah dan mudah digunakan. Meskipun demikian, dalam pembelajaran bahasa, WA masih kurang maksimal digunakan.Oleh sebab itu, melalui penelitian ini penulis ingin mencari dan menggali tentang bagaimana penggunaan aplikasi WA dalam pembelajaran bahasa Arab Serta prinsip dasar pemilihan media pembelajaran di era industry 4.0

Metode penelitian yang digunakan adalah dengan kualitatif deskriptif. Dengan demikian data yang digunakan berbasis library research. dengan menela'ah dan menelusuri berbagai literatur kepustakaan. Data dicari melalui teks-teks baik dalam buku maupun artikel dan dikumpulkan kemudian dianalisis dan direduksi secara deduktif untuk menghasilkan hasil penelitian yang dinarasikan secara deskriptif.

Tahapan dari pengumpulan data yaitu: melakukan pengumpulan beberapa literature terkait fokus penelitian, menelaah dan memisah-misahkan antara data yang dibutuhkan dan tidak, mereduksi data yang diperoleh dan terakhir dengan melakukan conclusion/menyimpulkan secara deskriptif. ${ }^{3}$

\section{Hasil danPembahasan}

Pembelajaran bahasa Arab harus dilakukan dengan tujuan ketrampilan berbahasa. Ketrampilan setiap bahasa pada dasarnya sama sehingga itu menjadi ukuran seseorang apakah dia menguasai bahasa tertentu atau tidak. Ketrampilan berbahasa yang dimaksud yaitu: ketrampilan menyimak (istima), berbicara (kalam), membaca (membaca), dan menulis (kitabah).

Pembelajaran merupakan satu kegiatan yang dirancang guru untuk 
menyampaikan materi kepada peserta didik sesuai dengan tujuan dan kompetensi pembelajaran. Dalam pembelajaran, seharusnya guru memahami beberapa hal mulai dari karakteristik peserta didik, tujuan pembelajaran, serta sarana yang dapat digunakan untuk mempermudah dalam menyampaikan materi ajar, dan juga instrument penilaian untuk mengukur sejauh mana keberhasilan pengajaran itu dilakukan. ${ }^{4}$

Adapun pembelajaran bahasa Arab itu sendiri bisa dimaknai sebagai proses penyampaian sebuah ilmu atau pengetahuan dari seorang guru kepada peserta didiknya menggunakan bahasa Arab dengan harapan agar peserta didik dapat memahami dan kemudian mampu mengembangkannya. ${ }^{5}$

Selain itu, prinsip pembelajaran bahasa Arab juga harus dipahami oleh guru sehingga kegiatan belajar mengajar yang dilakukan bisa berjalan dengan baik. Abdul Hamid menyebutkan bahwa prinsip pembelajaran bahasa Arab terbagi menjadi tiga: ${ }^{6}$ pertama, prinsip perencanaan; pada prinsip ini guru membuat perencanaan yang matang tentang materi apa yang akan diajarkan serta perangkat yang digunakan dalam pembelajaran, kedua, prinsip pelaksanaan; pada pelaksanaan pembelajaran guru harus mengerti tentang tahapan-tahapan yang akan dilakukan ketika mengajar, hal ini membuat materi yang disampaikan mudah untuk dipahami, ketiga, prinsip evaluasi; setelah mengajar, guru seharusnya melakukan evaluasi terhadap proses belajar mengajar yang sudah dilakukan untuk mengetahui sejauh mana keberhasilannya. Tujuan lain dari evaluasi ini juga dijadikan sebagai bahan perbaikan guru ketika melaksanakan proses pengajaran selanjutnya.

\section{Bahasa Arab di Era Industri 4.0}

Istilah revolusi industri 4.0 sebenarnya bukanlah nama baru karena revolusi industri ini sudah dikenal di Jerman sejak tahun 2011. Hakikat dari revolusi industri adalah terjadinya kemajuan besar- besaran yang disertai dengan perubahan sosial budaya secara signifikan. ${ }^{7}$ Perubahan yang terjadi di era revolusi industry 4.0 adalah terjadinya kebutuhan manusia terhadap media digital dalam membuat dan memproduksi sesuatu. Mereka dimudahkan dengan adanya beberapa layanan digital dalam banyak hal dan kegiatan, begitu juga dalam proses belajar mengajar.

${ }^{4}$ Teatantia and Nurhadi, "Pengembangan Media Pembelajaran Bahasa Arab Berbasis Portable Engkklek Arabic," Al Mahara (Jurnal Pendidikan Bahasa Arab) 6 (2020): 6.

${ }^{5}$ Anshor Muhtadi Ahmad, "Pengajaran Bahasa Arab Media Dan Metode-Metodenya" (Yogyakarta: Teras, 2009), 6.

${ }^{6}$ Nurul Hidayatul Amalina and Muh. Nashirudin, "Analisis Proses Pembelajaran Bahasa Arab Pada Tingkat Tsanawiyah Di Pon. Pes Ta'mirul Islam," TS AQIF (Jurnal Pemikiran Dan Penelitian Pendidikan) 15 (2017): 7.

${ }^{7}$ Reflianto Syamsuar, "Pendidikan Dan Tantangan Pembelajaran Berbasis Teknologi Informasi Di Era Revolusi Industri 4.0,” E-Tech; Jurnal Ilmiah Teknologi Penddikan, 2008, 2. 
Bahasa Arab sebagai bahasa asing yang dipelajari oleh pelajar Indonesia tentu menghadapi beberapa problem dalam proses pembelajarannya. Di samping pemilihan metode pembelajaran yang tepat, guru juga dianjurkan menggunakan metode yang dapat mempermudah dalam menyampaikan materi pelajaran. Media selalu akan berkembang sesuai kondisinya. Midun menyebutkan bahwa media digunakan dalam pembelajaran dimulai sejak abad 17 beriringan dengan munculnya satu aliran yang dipelopori oleh Johan Amos Camenius yaitu aliran realisme dalam pendidikan. Aliran inilah yang menjadikan lahirnya aliran visual dalam pembelajaran, yaitu aliran yang menganggap bahwa pembelajaran dengan menggunakan media gambar dapat mempermudah peserta didik dalam memahami sesuatu yang sulit dijelaskan secara lisan serta dapat membuat apa yang disampaikan semakin jelas. Perkembangan media kemudian yaitu pada tahun 1930 dengan munculnya aliran audio-visual dalam pendidikan yang didukung dengan ditemukannya radio. ${ }^{8}$

Yunus pernah menyampaikan dalam bukunya yang berjudul at tarbiyatu wata'lim "media pembelajaran memiliki pengaruh yang paling besar bagi indra serta memberikan pemahaman yang kuat bagi seseorang. Orang yang hanya mendengar suatu cerita, tentu akan berbeda dengan orang yang mendengar serta melihatnya secara langsung." Pemahaman dari sesuatu yang dilihat jauh lebih kuat dari sekedar penjelasan melalui cerita saja. Hal ini sejalan dengan apa yang disampaikan oleh Azhar Arsyad, beliau mengatakan "media pembelajaran dapat membawa dan meningkatkan rasa senang serta gembira bagi para pelajar di samping juga dapat menggairahkan semangat belajar mereka. ${ }^{10}$

Media sendiri diambil dari bahasa latin dengan bentuk banyak yang diambil dari kata medium. Secara bahasa media memiliki makna tengah, perantara, maupun pengantar. Dengan demikian, media bisa dimaknai sebagai penengah atau perantara untuk mengirim sesuatu kepada penerimanya ${ }^{11}$. Adapun dalam bahasa Arab media dikenal dengan istilah wasail yang memiliki arti perantara atau pengirim pesan dari pengirim kepada yang menerimanya. ${ }^{12}$

Adapun media ini ketika berkaitan dengan pembelajaran bahasa Arab bisa difahami sebagai alat yang dimanfaatkan pengajar bahasa Arab dalam proses belajar mengajar untuk mempermudah peserta didik dalam memahami pelajaran. Dengan pemanfaatan media, diharapkan tujuan pembelajaran dapat tercapai.

${ }^{8}$ Nunuk Rialita, "Era Revolusi Industri 4.0, Pembelajaran PT Harus Lebih Inovatif," Tabularasa PPS Unimed, 2018, 130-39.

'Abdul Wahab Rosydi, "Media Pembelajaran Bahasa Arab" (Malang: UIN Malang Press, 2009), 25.

${ }^{10}$ Azhar Arsyad, "Media Pembelajaran, 16"

${ }^{11}$ Arif S. Sadiman dkk, "Media Pendidikan: Pengertian, Pengembangan Dan Pemanfaatannya" (Jakarta: PT Raja Grafindo Persada, 2006), 6.

${ }^{12}$ Hilmi, "Efektifitas Penggunaan Media Gambar Dalam Pembelajaran Bahasa Arab. Lantanida, 2016, h. 129," Lantanida, 2016. 
Media pembelajaran bahasa Arab yang dapat digunakan sangat beragam ada yang berbentuk audio dan ada juga yang visual. Sejalan dengan hal itu, linguis Arab Mahmud Ismail Shinny juga menyebutkan bahwa secara umum media pembelajaran bahasa Arab terbagi atas tiga bagian besar, yaitu: media audio, media visual, dan media audio visual. ${ }^{13}$

Media pembelajaran yang berbasis audio seperti kaset, rekaman, radio dan suara lain yang bisa dimanfaatkan untuk pembelajaran. Adapun di antara contoh media visual seperti kartun, kartu, gambar dan lain sebagainya, sedangkan media audio-visual seperti rekaman video, televise, film dan lain-lain.

Melihat pentingnya media dalam pembelajaran maka guru tidak boleh mengabaikan begitu saja. Guru harus jeli untuk memilah dan memilih media yang dapat mempermudah dalam menyampaikan pelajaran. Dilihat dari manfaatnya, media dalam pengajaran memberikan beberapa manfaat: ${ }^{14}$

1. Meningkatkan kualitas pendidikan dengan meningkatkan kecepatan belajar

2. Memberi kemungkinan yang sifatnya lebih individual

3. Membuat dasar pengajaran menjadi lebih ilmiah

4. Pengajaran dapat dilaksanakan secara mantap

5. Meningkatkan terwujudnya kedekatan belajar

6. Menyajikan pembelajaran secara ilmiah.

Di samping itu, mengutip penelitian yang ditulis oleh Ahmad ibn Abd Rahman as-Simarra'i, belia mengatakan bahwa tingkat pencapaian seseorang dalam memahami sesuatu melalui penglihatan dapat mencapai $75 \%$, adapaun ketika seseorang hanya mendengar saja hanya $13 \%$, dan dengan menggunakan indra yang lain seperti sentuhan, penciuman, dan pengecapan hanya memberikan pemahaman atau pengetahuan sebesar $12 \%$. Sehingga ia mengatakan bahwa tempat belajar yang diberi tempelan gambar-gambar akan lebih kuat tiga kali lipat dalam memberikan pemahaman kepada seseorang, terlebih ketika gambar tersebut dipadukan dengan cerita atau suara akan lebih baik dibanding dengan ceramah kata-kata saja. ${ }^{15}$ Hasil penelitian ini seharusnya menjadi perhatian bagi pengajar bahasa Arab sehingga dapat memberikan motivasi untuk mengembangkan media pembelajaran yang digunakan.

\section{Kriteria Pemilihan dan Penentuan Media dalam Pembelajaran di Era 4.0}

Meskipun sudah dimaklumi dan disepakati bahwa media dapat membantu dan mempermudah pembelajaran, seorang pengajar juga harus jeli dalam memilih media pembelajaran. Mereka harus memahami situasi dan

${ }^{13}$ Hilmi.16

${ }^{14}$ Nunu Mahnun, "MEDIA PEMBELAJARAN (Kajian Terhadap Langkah-Langkah Pemilihan Dan Implementasinya Dalam Pembelajaran)," Pemikiran Islalm, n.d., 27.

${ }^{15}$ Yasmarudin Bardansyah, "Urgensi Penciptaan Lingkungan Berbahasa Asing (Makalah)," 2008. 4 
kondisi serta karakteristik dari media itu sendiri, mulai dari kelebihan dan kelemahannya ketika digunakan.

Untuk menentukan dalam memilih media pembelajaran, kita bisa membaca dari apa yang disampaikan oleh Ahmad Khairi yang menjelaskan tentang azaz pemilihan media pembelajaran. Azaz penentuan media yang akan dimanfaatkan dalam pembelajaran bisa ditentukan dari jawaban beberapa pertanyaan sebagai berikut: sejauh mana tujuan pembelajaran dapat tercapai dengan menggunakan media yang dipilih? ${ }^{16}$, apakah media yang digunakan sesuai dengan perkembangan atau umur peserta didik?, apakah media yang digunakan dapat memberikan pemahaman lebih jelas terhadap materi pelajaran?, apakah media itu efisien baik segi waktu dan biaya untuk digunakan?, dan apa kelebihan dan kelemahan dari media tersebut?Pertanyaan-pertanyaan tersebut menjadi acuan dalam memilih dan menentukan media.

Oleh karena itu, sebelum menentukan media guru harus mengetahui adanya prinsip-prinsip sebagai bahan pertimbangan. Di antara prinsip-prinsip tersebut yaitu:

1. Kejelasan maksud dan tujuan media, yaitu kejeliaan dalam melihat tujuan media yang harus dihubungkan dengan manfaat penggunaannya. Tujuan yang bermacam-macam dari media tersebut harus diperjelas sehingga manfaatnya bisa maksimal, seperti apakah hanya sekedar untuk mengisi waktu luang, hiburan, dan memberi informasi umum. Kalau tujuan media di luar untuk pembelajaran, maka itu sudah keluar dari penggunaan media dalam belajar. ${ }^{17}$

2. Adanya familiaritas, media yang digunakan harusnya familiar dan mudah digunakan, baik oleh guru atau peserta didik itu sendiri. Media yang bisa dijangkau penggunaan dan biayanya membuat peserta didik lebih cepat adaptif sehingga pembelajaran tidak akan terhambat. Sebaliknya, media yang tidak familiar akan membuat peserta didik cenderung malas karen harus focus terhadap penggunaan media itu sendiri bukan pada materi pelajarannya.

3. Adanya media pembanding, setiaip media pembelajaran memiliki karekteristik yang berbeda-beda. Meskipun demikian, guru harus mengetahui dan menyiapkan beberapa media sebagai pembanding antara satu dengan yang lain. Dengan melakukan demikian, guru akan mengetahui kualitas setiap media yang digunakan. Dengan demikian, semakin banyak media pembelajaran yang tersedia maka akan semakin baik jug pembelajaran berlangsung. ${ }^{18}$

\footnotetext{
${ }^{16}$ Hilmi, "Efektifitas Penggunaan Media Gambar Dalam Pembelajaran Bahasa Arab. Lantanida, 2016, h. 131."

${ }^{17}$ Anderson, "Pemilihan Dan Pengembangan Media Untuk Pembelajaran" Jakarta: Paut \& CV Rajawai, 1983), 19.

18Zainul Abidin, "Penerapan Pemilihan Media” (Malang: UM, 2017), 11.
} 
4. Adanya kriteria sebagai pedoman penentuan media, setiap media yang digunakan dalam pembelajaran tentu ditujukan untuk membantu terwujudnya tujuan pembelajaran itu sendiri. Akan tetapi guru harus jeli dengan media yang akan dipilih, ia harus tahu kekurangan dan kelebihan media tersebu, serta melihat kondisi yang ada. Misalnya, Guru tidak bisa memaksakan media online sebagai sarana pembelajaran sedangkan di lingkungan belajar belum tersedia jaringan yang baik. Selain itu, pengembangan kriteria dan penentuan media harus dilakukan sehingga dapat mengetahui apakah media yang akan digunakan itu by design atau by utilizitation, karenamedia yang ditentukan tersebut akan memiliki konsekuensi dan berdampak pada kriteria atau norma yang digunakan. Media yang dimaksud by design yaitu media yang dirancang dengan sengaja untuk tujuan tercapainya target sebuah pembelajaran adapun media by utilizitation yaitu media yang secara umum sudah dikenal dan tersedia sehingga tinggal menggunakannya untuk sesuatu yang diinginkan. Oleh karena itu, baik media by design maupun media by utilizitation memiliki kriteria yang berbeda sebagai pedoman penggunaannya.

Pembelajaran di Era abad 21 mengalami pergeseran dari yang manual tradisional ke arah yang berbasis digital yang lebih modern sesuai dengan perkembangan teknologi dan tuntutan industry 4.0. Oleh karena itu, untuk mewujudkan kondusifitas dalam pembelajaran serta mencetak generasi yang tidak gagap dengan teknologi dan peka terhadap kemajuan informasi di abad 21, maka diperlukan strategi pembelajaran sebagai berikut: ${ }^{19}$

1. Fokus belajar pada kegiatan belajar mengajar lebih dalam serta menekankan pada praktik secara langsung serta cara bermitra dengan yang lain. Belajar lebih dalam membuat peserta didik memahami intisari dari apa yang dipelajari dalam satu peristiwa dan mengaplikasikan kepada peristiwa yang lain.

2. Strategi yang diaplikasikan dalam pembelajaran adalah strategi paedagogik yang mendukung deeper learning dan kemitraan. Hal tersebut bertujuan supaya peserta didik mampu beradaptasi dengan masyarakat serta membaur tanpa memiliki sikap individualis

3. Pembelajaran diarahkan kepada model pembelajran penemuan (inquiry based model. Pembelajaran ini adalah berbasis masalah di mana pesertadidik dilatih untuk menmukan solusinya sehingga di kemudian hari akan menjadi manusia yang terampil dan cekatan.

4. Teknologi dimanfaatkan untuk membantu peserta didik mengembangkan ketrampilan mereka berbasis teknologi sebagai wujud peningkatan kompetensi pada abad 21. Pemanfaatan ini harus menjadikanpeserta didik aktif berpatisipasi sehingga mereka bisa dan terbiasa dengan perkembangan teknologi informasi di era 4.0

\footnotetext{
${ }^{19}$ Armelia Yuniani., dkk, "Era Revolusi 4.0: Peran Media Sosial Dalam Pembelajaran Fisika Di SMA,” GRAVTTASI, 2019, 19.
} 
5. Pembelajaran informal dan pengalaman ditekankan untuk menjadikan mereka memiliki kemampuan dan kompetensi yang lain di luar dari apa yang sudah mereka pelajari dan dapatkan di kelas.

Adapun pembelajaran bahasa Arab ketika akan disesuaikan dengan era industry 4.0, maka harus memperhatikan terhadap prinsip dasar dari pembelajaran era 4.0 itu sendiri. Prinsip dari pembelajaran era 4.0 yaitu dikenal dengan istilah 4C sebagai kebutuhan primer bagi peserta didik untuk melatih kemampuan dan bakat mereka dalam menghadapi era 4.0.

Karakteristik dari istilah 4C itu sendiri bisa kita fahami melalui maknanya yaitu: communication, collaboration, critical thinking and problem solving, creativity and innovation. Ke empat prinsip dasar inilah yang harus diwujudkan dalam pembelajaran bahasa Arab guna menyesuaikan dengan era 4.0. oleh sebab itu, perangkat pembelajaran yang digunakan seperti media juga harus disesuaikan sehingga akan stimulus bagi peserta didik serta membuat mereka tidak malas dan bosan untuk belajar.

\section{Media Whatsaap dalam Pembelajaran Bahasa Arab}

Whatsap atau WA menjadi media komunikasi yang trend digunakan saat ini. Hamper setiap orang menggunakan aplikasi ini dalam komunikasi dan berinteraksi sehari-hari. Aplikasi ini memiliki beberapa kelebihan sehingga menjadikan orang tertarik untuk menggunakannya. Aplikasi ini bisa digunakan untuk mengirim pesan baik berbentuk tulisan, gambar, suara bahkan video sekalipun. Di samping itu juga, seseorang dapat melakukan panggilan maupun telpon bahkan dengan video call.

Dari keunggulan tersebut, media ini bisa dijadikan sebagai alat untuk mewujudkan pembelajaran bahasa Arab. Seperti halnya ketika mengajarkan kemahiran berbicara, guru bisa menggunakan WA untuk berkomunikasi dengan peserta didiknya. Guru bisa memantau dengan mendengarkan suara peserta didik secara langsung sebagai wujud respon dari apa yang diharapkan. Lebih dari itu, untuk mengecek secara langsung apakah murid melihat teks atau tidak dalam berbicara, guru bisa menggunakan video yang sudah disediakan oleh aplikasi WA ini.

Melalui aplikasi ini, guru dapat membuat grup bagi peserta didiknya dan menyusun agenda kegiatan belajar mengajar bahasa Arab, seperti halnya menyampaikan beberapa kalimat yang tidak sempurna kemudian meminta peserta didik untuk menyempurnakannya melalui WA baik secara lisan maupun tulisan. ${ }^{20}$ Sebagaimana dikatakan juga oleh Al Salem bahwa di dalam WA terdapat layanan grup yang mampu membuat pembelajaran lebih menyenangkan 2017,5 .

${ }^{20}$ M. Arif Mustofa, “Asalib Tadris al Lughoh al Haditsah. an-Nabighah," An Nabighoh, 
dengan mendiskusikan tema-tema tertentu yang diberikan oleh guru. ${ }^{21}$ Oleh karena itu, dengan suasana belajar yang menyenangkan akan menjadikan motivasi peserta didik dalam belajar meningkat.

Aplikasi Whatsapp menyediakan beberapa layanan yang bisa dimanfaatkan utuk pembelajaran. Kelebihan dari aplikasi ini yaitu:

1. WA Memiliki aplikasi yang lengkap, aplikasi ini dapat mengirim gambar, video, suara, teks, alamat (gps), bahkan bisa video call.

2. Adanya tanda yang menununjukan status apakah pesan tersebut telah diterima, dibaca ataupun belum.

3. Adanya fasilitas grup chat yang mudah dan murah untuk dibuat serta ringan digunakan

4. Mampu digunakan untuk melakukan komunikasi dan diskusi secara bersamaan dalam waktu yang sama tanpa harus bertemu secara langsung.

5. Mempermudah dalam menyebarkan informasi dan mempublikasikan sesuatu dalam bentuk yang bermacam-macam. ${ }^{22}$

Oleh karen itu, dengan kelebihan yang dimiliki Whatsapp penggunanya lebih banyak jika dibandingkan dengan media komunikasi online (chat) yang lain. ${ }^{23}$ Pembelajaran bahasa Arab berdasarkan ketrampilannya dengan menggunakan whatsapp sebagai berikut

\section{Pengajaran maharah istima's maharah al kalam}

Istima' adalah bagian dari ketrampilan bahasa mendasar yang terbentuk dari kata sami'a (mendengar. Adapun istima' itu sendiri memiliki makna memperhatikan dan mendengarkan. ${ }^{24}$ Tujuan dari pembelajaran istima' itu sendiri yaitu: penguasaan, pemahaman, penjabaran, penafsiran, derivasi, dan proses peningkatan IQ. ${ }^{25}$ Dengan demikian, kemampuan mendengar yang baik akan menghasilkan pemahaman dan mampu merespon secara cepat dan tepat.

Adapun pengajara istima' dengan menggunakan WA bisa dilakukan dengan beberapa langkah sebagai berikut:

a. Guru menyiapkan teks yang akan diperdengarkan kepada peserta didik

b. Guru mengirim suara bacaan teks tersebut kepada peserta didik melalui WA

\footnotetext{
${ }^{21}$ Basma Issa Ahmad Alsaleem, ““” The Eff Ect of 'WhatsApp' Electronic Dialogue Journaling on Improving Writing Vocabulary Word Choice and Voice of EFL Bostonhlm" (Undergraduate Saudi Students" Offi cial Proceedings 21st Century Academic Forum Conference at Harvard, Boston, 2014).

22Jumiatmoko, "Whatsapp Messenger Dalam Tinjauan Manfaat Dan Adab," Wahana Akademika 3 (2016): 55.

${ }^{23}$ Rani Suryani, "Fungsi Whatsapp Grup Shalehah Cabang Bandar Lampung Sebagai Pengembangan Media Dakwah Dalam Membentuk Akhlakul Kharimah," 2017.

${ }^{24}$ Fairuz Abadi, "Al-Qomus al-Muhith, Sami’a," vol. 8 (Lisan al Araby, n.d.), 943-44.

${ }^{25}$ Qomi Akid Jauhari, "Pembelajaran Maharah Istima' Di Jurusan PBA UIN Malang, Tarbiyatuna," Tarbiyatuna 3 (2018).
} 
c. Setelah mendengar, siswa diminta untuk mengulangi (pemula) dan menjawab pertanyaan berkaitan dengan teks yang diperdengarkan bagi tingkat lanjutan.

Semua itu dilakukan dengan memanfaatkan aplikasi WA pesan suara, sehingga guru akan mudah melakukan pengajaran meskipun tidak tatap muka.

Adapunmaharah al kalam adalah kemahiran berbicara yang menjadi bagian dasar dari pengajaran semua bahasa. Dengan berbicara, orang dapat dengan mudah berkomunikasi dan berinteraksi dengan yang lain. Pembelajaran mabarah al kalam dalam bahasa Arab akan mudah dilaksanakan jika guru dan peserta didik aktif. Semakin aktif dalam praktik berbicara maka semakin cepat juga seseorang akan mampu menguasai bahasa lisan dalam satu bahasa. Sehingga ada istilah yang mengatakan, belajar membaca dengan membaca dan belajar berbicara juga dengan berbicara. ${ }^{26}$ Oleh karena itu, guru dituntut untuk menciptakan pembelajaran yang dapat membuat peserta didik aktif dalam praktik maharah al kalam.

Adapun pengajaran kemahiran berbicara bahasa Arab dengan menggunakan WA maka guru dapat melakukan beberapa hal:

a. Membentuk grup terlebih dahulu dalam WA

b. Menanyakan kabar melalui pesan suara dengan menggunakan bahasa Arab

c. Memberikan tema tertentu untuk menjadi bahan pembicaraan antara peserta didik satu dengan yang lain maupun guru dan peserta didik itu sendiri

Dalam evaluasinya guru bisa melakukan video call kepada masingmasing peserta didik baik per orangan maupun beberapa orang secara bersamasama.Berikut gambar yang dilakukan dalam pengajaran mubadatsab dan evaluainya dengan melakukan video call pada setiap peserta didik.
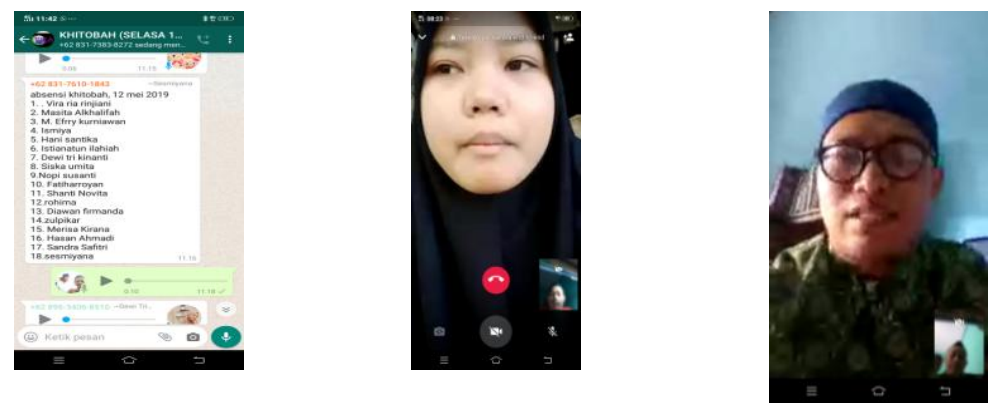

Kegiatan yang dilakukan tersebut baik pembelajaran melalui grup maupun video call terhadap masing-masing peserta didik dengan menggunakan bahasa Arab.

${ }^{26}$ Darwati Nalole, "Meningkatkan Keterampilan Berbicara Melalui Metode Muhadatsah Dalam Pembelajaran Bahasa Arab," Al Minhaj 1 (2018): 2. 


\section{Pengajaran maharah al Qiroaah dan al Kitabah}

Keterampilan bahasa Arab selanjutnya adalah membaca. Peserta didik dalam belajar bahasa disamping mampu berbicara harus juga mampu untuk membaca teks bahasa Arab. Kemampuan membaca dimulai dari tingkat yang mendasar (membaca huruf) sampai dengan membaca kalimat teks bahasa Arab. Kemampuan peserta didik dalam kemahiran membaca dianggap baik ketika peserta didik mampu membaca teks sesuai dengan struktur dan makhrajnya serta memahami kandungan maknanya. Kemahiran dalam membaca teks bahasa Arab itu sendiri bisa diukur dengan melihat: bunyi huruf maupun teks yang diucapkan, kemampuan mengenali struktur dalam teks dengan memberikan syakkal, dan memahami makna dari teks yang diucapkan. ${ }^{27}$ Dengan adanya indicator ini, peserta didik dapat dinilai apakah sudah menguasai maharah qiroah atau belum.

Pengajaranmaharah qiroah menggunakan WA bisa dilakukan dengan:

a. Menentukan tujuan pembelajaran yang akan dicapai

b. Menyiapkan teks yang akan diajarkan

c. Mengirim teks bahasa Arab melalui WA

d. Meminta peserta didik untuk membaca teks tersebut dan mengirimkan bacaaannya melalui pesan suara

e. Bagi tingkat lanjutan, peserta didik diminta untuk memberikan syakkal dan menjelaskan maknanya, kemudian mengirimkannya kembali melalui WA serta mendiskusikannya dalam grup.

Keterampilan bahasa yang terakhir untuk diajarkan adalah keterampilan menulis, keterampilan menulis adalah bagian dari bahasa tulisan. Keterampilan menulis bagian yang tertinggi di antara keterampilan bahasa yang lain,karena menuntut aspek pengetahuan dan pemikiran mendalam yang dinarasikan melalui tulisan dengan kaidah yang benar. yang Tujuan dari keterampilan menulis atau yang dalam bahasa Arab disebut maharah kitabah secara umum adalah membentuk huruf, memperbaiki tulisan dan mengekspresikan ide dan perasaan dengan tulisan. ${ }^{28}$ Tujuan yang terakhir inilah yang menjadi pokok dari kemahiran ini.

Adapun pengajaran kemahiran menulis bahasa Arab menggunakan media WA sebagai berikut:

a. Menyiapkan grup dalam belajar WA

b. Menyiapkan materi yang akan diajarkan baik berupa video cara menulis (pemula) maupun teks yang akan diajarkan

\footnotetext{
${ }^{27}$ Ahmad Rathomi, "Pembelajaran Bahasa Arab Maharah Qiroah Melalui Pendekatan Sintifik," Ta'dib: Jurnal Pendidikan Islam 8 (2019): 562.

${ }^{28}$ Fajriah, "Starategi Pembelajaran Maharah al Kitabah Pada Tingkat Ibtidaiyah," PIONIR Jurnal Pendidikan 6 (2017): 36.
} 
c. Mendikte huruf (bagi pemula) atau beberapa kalimat untuk ditulis oleh peserta didik dan dikirim melalui WA

d. Memberikan beberapa teks yang tidak lengkap kemudian meminta peserta didik untuk melengkapinya, teks tersebut bisa difhoto maupun langsung ditulis menggunakan WA

Meskipun demikian, penggunaan Whatsapp untuk media pembelajaran memiliki kelemahan. Secara umum ketika aplikasi ini diterapkan menggunakan $\mathrm{hp} /$ android maka memori atau space tempat yang disediakan android itu sendiri tidak memadai sehingga membuat operasionalnya menjadi lebih lambat dan cenderung mudah error.

\section{Penutup}

Pembelajaran bahasa Arab yang berlangsung saat ini harus menyesuaikan dengan perkembangan teknologi. Memasuki era industry 4.0 banyak aplikasi yang bisa dimanfaatkan dalam pembelajaran bahasa Arab. Media pembelajaran yang digunakan harus tetap berpegang pada prinsip: kejelasan maksud dan tujuan media, familiar, serta adanya panduan yang jelas dalam pemanfaatannya.Adapun pembelajaran bahasa Arab menggunakan media WA bisa dilakukan dengan memperhatikan aspek keterampilan yang akan diajarkan sehingga antara satu keterampilan bahasa dengan yang lain bisa diukur dan dievaluasi dengan cara yang berbeda. Grup menjadi pokok dalam pembelajaran bahasa Arab melalui WA di samping layanan foto, video, pesan suara, gambar yang digunakan. Semua layanan ini harus disesuaikan dengan keterampilan bahasa maupun tujuan yang ingin dicapai.

\section{Bibliografi}

Abdul Wahab Rosydi. "Media Pembelajaran Bahasa Arab," 25. Malang: UIN Malang Press, 2009.

Ahmad Rathomi. "Pembelajaran Bahasa Arab Maharah Qiroah Melalui Pendekatan Sintifik." Ta'dib: Jurnal Pendidikan Islam 8 (2019): 562.

Anderson. "Pemilihan Dan Pengembangan Media Untuk Pembelajaran," 19. Jakarta: Paut \& CV Rajawai, 1983.

Anshor Muhtadi Ahmad. "Pengajaran Bahasa Arab Media Dan MetodeMetodenya," 6. Yogyakarta: Teras, 2009.

Arif S. Sadiman dkk. "Media Pendidikan: Pengertian, Pengembangan Dan Pemanfaatannya," 6. Jakarta: PT Raja Grafindo Persada, 2006.

Armelia Yuniani., dkk. "Era Revolusi 4.0: Peran Media Sosial Dalam Pembelajaran Fisika Di SMA.” GRAVITASI, 2019, 19. 
Azhar Arsyad. "Media Pembelajaran," 3. Jakarta: PT Raja Grafindo Persada, 2007.

Basma Issa Ahmad Alsaleem. ““، The Eff Ect of 'WhatsApp' Electronic Dialogue Journaling on Improving Writing Vocabulary Word Choice and Voice of EFL Bostonhlm." Presented at the Undergraduate Saudi Students" Offi cial Proceedings 21st Century Academic Forum Conference at Harvard, Boston, 2014.

Darwati Nalole. "Meningkatkan Keterampilan Berbicara Melalui Metode Muhadatsah Dalam Pembelajaran Bahasa Arab." AlMinhaj 1 (2018): 2.

Fairuz Abadi. "Al-Qomus al-Muhith, Sami'a," 8:943-44. Lisan al Araby, n.d.

Fajriah. "Starategi Pembelajaran Maharah al Kitabah Pada Tingkat Ibtidaiyah." PIONIR Jurnal Pendidikan 6 (2017): 36.

Hilmi. "Efektifitas Penggunaan Media Gambar Dalam Pembelajaran Bahasa Arab. Lantanida, 2016, h. 129." Lantanida, 2016.

Ibn Jinni \& Abd. Fatah, Utsman. Al-Khashais. Bairut: Alam al-Kutub, n.d.

Jumiatmoko. "Whatsapp Messenger Dalam Tinjauan Manfaat Dan Adab." Wabana Akademika 3 (2016): 55.

M. Arif Mustofa. "Asalib Tadris al Lughoh al Haditsah. an-Nabighah." An Nabighoh, 2017, 5.

Nunu Mahnun. "MEDIA PEMBELAJARAN (Kajian Terhadap LangkahLangkah Pemilihan Dan Implementasinya Dalam Pembelajaran)." Pemikiran Islalm, n.d., 27.

Nunuk Rialita. "Era Revolusi Industri 4.0, Pembelajaran PT Harus Lebih Inovatif." Tabularasa PPS Unimed, 2018, 130-39.

Nurul Hidayatul Amalina, and Muh. Nashirudin. "Analisis Proses Pembelajaran Bahasa Arab Pada Tingkat Tsanawiyah Di Pon. Pes Ta'mirul Islam.” TS AQIF (Jurnal Pemikiran Dan Penelitian Pendidikan) 15 (2017): 7.

Qomi Akid Jauhari. "Pembelajaran Maharah Istima' Di Jurusan PBA UIN Malang, Tarbiyatuna." Tarbiyatuna 3 (2018).

Rani Suryani. "Fungsi Whatsapp Grup Shalehah Cabang Bandar Lampung Sebagai Pengembangan Media Dakwah Dalam Membentuk Akhlakul Kharimah." 2017.

Reflianto Syamsuar. "Pendidikan Dan Tantangan Pembelajaran Berbasis Teknologi Informasi Di Era Revolusi Industri 4.0.” E-Tech; Jurnal Ilmiah Teknologi Penddikan, 2008, 2.

Sugiyono. "Model Penelitian Kuantitatif Kualitatif," 373. Bandung: Alfabeta, 2010.

Teatantia, and Nurhadi. "Pengembangan Media Pembelajaran Bahasa Arab Berbasis Portable Engkklek Arabic." Al Mahara (Jurnal Pendidikan Bahasa Arab) 6 (2020): 6.

Yasmarudin Bardansyah. "Urgensi Penciptaan Lingkungan Berbahasa Asing (Makalah),” 2008.

Zainul Abidin. "Penerapan Pemilihan Media," 11. Malang: UM, 2017. 